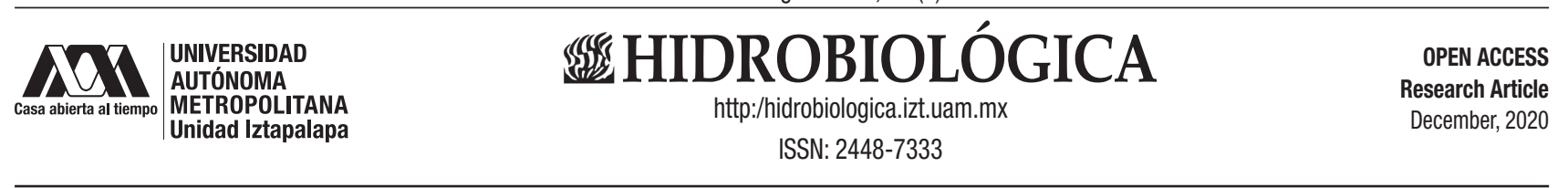

\title{
Density of mysis of Penaeus aztecus lves, 1891 on a reef in the Southwest of the Gulf of Mexico
}

\author{
Densidad de mysis de Penaeus aztecus Ives, 1891 en un arrecife del suroeste del Golfo de México
}

Sergio Cházaro-Olvera ${ }^{\star \star}$, Ángel Morán-Silva, Rafael Chávez-López ${ }^{1}$, Horacio Vázquez-López and Asela del Carmen Rodríguez-Varela

\footnotetext{
Grupo Académico y de Investigación Acuática (GAIA), Carrera de Biología, Facultad de Estudios Superiores Iztacala, Universidad Nacional Autónoma de México. Av. de los Barrios No.1, Los Reyes Iztacala Tlalnepantla, Estado de México, 54090 México.
}

*Corresponding author: Sergio Cházaro-Olvera: chazaro@campus. iztacala.unam.mx,schazaro@gmail.com

To quote as:

Cházaro-Olvera, S., Á. Morán-Silva, R. Chávez-López, H. Vázquez-López \& A. del C. Rodríguez-Varela. 2020. Density of mysis of Penaeus aztecus Ives, 1891 on a reef in the Southwest of the Gulf of Mexico. Hidrobiológica 30 (3): 233-242

DOl:10.24275/uam/izt/dcbs/hidro/2020v30n3/ Chazaro

\section{ABSTRACT}

Background. The Parque Nacional Sistema Arrecifal Veracruzano (PNSAV) is in the southern Gulf of Mexico and supports an important shrimp fishery based on three species of Dendrobranchiata: the brown shrimp, Penaeus aztecus, the white shrimp, P. setiferus and the pink shrimp, P. duorarum. Objective. Analyze the distribution and abundance of $P$. aztecus during the mysis stage and determine its relationship with environmental factors in the PNSAV. Methods. We measured temperature, salinity, and dissolved oxygen in situ. The planktonic samples from four transects were collected during cold fronts and rainy weather conditions from 2011 to 2013. Results. In rainy conditions the temperature varied from $27.49 \pm 0.46$ to $29.98 \pm 0.02^{\circ} \mathrm{C}$, salinity from $32.18 \pm 0.06$ to $35.40 \pm 0.52$, and dissolved oxygen from $3.64 \pm 0.13$ to $6.18 \pm 0.64 \mathrm{mgL}^{-1}$; during cold fronts the temperature varied from $23.21 \pm 0.05$ to $25.74 \pm 0.37{ }^{\circ} \mathrm{C}$, salinity from $34.59 \pm 0.39$ to $35.84 \pm 0.17$, and dissolved oxygen from $4.04 \pm 0.06$ to $6.02 \pm \mathrm{mgL}^{-1}$. The highest average density with $6,938 \pm 326$ mysis $100 \mathrm{~m}^{-3}$, was found during rainy season in 2011 in the southern transect nearshore, followed by $3,321 \pm 339$ mysis $100 \mathrm{~m}^{-3}$ in the offshoresouth-central transect during cold fronts weather conditions in 2013, and 3,056 \pm 236 mysis $100 \mathrm{~m}^{-3}$ in the south-central foreshore transect during cold fronts weather condition in 2011. Conclusions. The highest density of $P$. aztecus during mysis stage was recorded in southward foreshore area from PNSAV, during rainy conditions and related to large values of dissolved oxygen concentrations.

Key words: coral reef, ecology, fisheries, larvae, shrimp brown

\section{RESUMEN}

Antecedentes. El Parque Nacional Sistema Arrecifal Veracruzano (PNSAV) está ubicado en el sur del Golfo de México y soporta una importante pesquería de camarones basada en tres especies de Dendrobranchiata: el camarón café, Penaeus aztecus, el camarón blanco, P. setiferus y el camarón rosado, $P$ duorarum. Objetivo. Analizar la distribución y abundancia de $P$. aztecus en estadio de mysis y determinar su relación con los factores ambientales en el PNSAV. Métodos. Se midió la temperatura, la salinidad y el oxígeno disuelto in situ. Se recolectaron muestras planctónicas de cuatro transectos durante frentes fríos y condiciones climáticas lluviosas de 2011 a 2013. Resultados. La temperatura varió de $27.49 \pm 0.46$ a $29.98 \pm 0.02{ }^{\circ} \mathrm{C}$, la salinidad de 32.18 \pm 0.06 a $35.40 \pm 0.52$ y el oxígeno disuelto de $3.64 \pm 0.13$ a $6.18 \pm 0.64 \mathrm{mgL}^{-1}$ en época de lluvias. Durante los frentes fríos, la temperatura varió de $23.21 \pm 0.05$ a $25.74 \pm 0.37^{\circ} \mathrm{C}$, la salinidad de $34.59 \pm 0.39$ a 35.84 \pm 0.17 y el oxígeno disuelto de $4.04 \pm 0.06$ a $6.02 \pm \mathrm{mgL}^{-1}$. La densidad media más alta fue de 6,938 \pm 326 mysis $100 \mathrm{~m}^{-3}$, que se encontró durante las lluvias en 2011 en el transecto sur, cercano a la costa, seguido por $3,321 \pm 339$ mysis $100 \mathrm{~m}^{-3}$ en el transecto centro-sur, costa afuera durante los frentes fríos en 2,013 y 3,056 \pm 236 mysis $100 \mathrm{~m}^{-3}$ en el transecto centro-sur durante los frentes fríos en 2011, en la zona de la costa. Conclusiones. La mayor densidad de mysis de $P$. aztecus se registró en la zona de playa al sur del PNSAV, durante las condiciones de lluvia y se relacionó con el aumento de las concentraciones del oxígeno disuelto.

Palabras clave: arrecife de coral, ecología, pesca, larvas, camarón café. 


\section{INTRODUCTION}

The Parque Nacional Sistema Arrecifal Veracruzano (PNSAV) is a highly productive ecosystem (Rodríguez-Gómez et al., 2013), which is the reason it was designated as a Marine Protected Area under the classification of National Marine Park in 1992 (DOF, 1992, 2012) and has since been declared a Biosphere Reserve within the Man and the Biosphere Program (UNESCO, 2006) and registered as a Ramsar site (number 1346) (FIR, 2004). This reef system is comprised of several individual coral reefs, divided into northern and southern groups by the influence of the fluvial plume of the Jamapa River (Horta-Puga et al., 2016).

Coral reef ecosystems such as PNSAV show an intricated architectural complexity (Jordán-Dahlgren, 2004), and support benthic and planktonic invertebrate assemblages of high biodiversity (Horta-Puga et al., 2007).Some of the zooplankton biota found in the PNSAV have been studied, such as appendicularians, chaetognaths, pteropods, copepods, as well as fish species (Flores-Coto, 1965, 1974; Leal-Rodríguez, 1965; Vega-Rodriguez, 1965; Aguayo-Saviñon, 1966; Campos, 1980; 1980; Suárez, 1992; Campos-Hernández \& Suárez-Morales, 1994; Ayala-Rodríguez et al., 2016). Okolodkov et al. (2011) conducted a study on the biomass of plankton, reporting that invertebrates are the most abundant group of zooplankton in this reef system. Cházaro-Olvera et al. (2019) found that $13.77 \%$ of the community of zooplankton were decapods, including commercial species such as Callinectes sp., Menippe sp., and Penaeus sp. Around 259 species of Crustacea have been found in the PNSAV, nine species belonging to suborder Dendrobranchiata (Hermoso-Salazar \& Arvizu-Coyotzi, 2015).

The PNSAV is located in the southern Gulf of Mexico and this region supports an important shrimp fishery based on three species of Dendrobranchiata: the brown shrimp, Penaeus aztecus Ives, 1891, the white shrimp, P. setiferus Linnaeus, 1767, and the pink shrimp, $P$. duorarum Burkenroad, 1939 (Gracía \& Soto, 1990; Gómez-Ponce et al., 2018).

The shrimp fishery is the fourth most important by catch volume in the Gulf of Mexico. Almost $80 \%$ of total capture corresponds to $P$. aztecus, caught mainly in theTamaulipas and Veracruz states; in the latter, between the years 2004 and 2013, up to 10\% of Gulf of México total catch was obtained (INP, 2014).

All Penaeus spp. stages are free living, the three commercially important penaeids spawn eggs in coastal waters, usually at depths of $<50 \mathrm{~m}$. The larvae become planktonic after hatching and transitioning through a series of stages, i.e., nauplius, zoea (including protozoea and mysis stages), and later, as tidal and wind-driven currents carry the larvae shoreward, the decapodid and juvenile stages eventually enter the estuary, become demersal, and move into coastal marshes to feed and grow before returning to shelf waters as sub-adults (Ditty \& Alvarado, 2011; Martin et al., 2014). Larval development is regular anamorphic (Anger, 2001), meaning that the appearance of characters and shape changes are gradual.

The brown shrimp, P. aztecus, typically occur from the west of the Mississippi River Delta to the Mexican State of Tamaulipas, however, they have also been caught from Martha's Vineyard, Massachusetts, to the Florida Keys, and in the west and south of the Gulf of Mexico, from Apalachicola Bay, Florida, to the northwestern coast of the Yucatan Peninsula, Mexico (Felder \& Camp, 2009). Spawning peaks of $P$. aztecus occur from December to April (Zimmerman \& Minello, 1984; Rozas \& Reed, 1993; Matthews, 2008) and a smaller, secondary peak occurs during late summer and early fall (Rogers et al., 1993).

The pelagic larval stage dispersion is considered to be an advantage for this species because it enhances genetic flow and the colonization of new areas.

The transport of penaeid larvae and postlarvae is a complex process that includes mechanisms such as selective tidal transport induced by synchronized salinity changes (Hughes, 1969), endogenous rhythms (Hughes, 1972), or hydrostatic pressure (Forbes \& Benfield, 1986; Rothlisberg et al., 1995). Another hypothesis suggests that changes in coastal water temperature, salinity, and the direction of currents, in combination with the diel movements of larvae and postlarvae, facilitate their transport (Hughes, 1969; Rogers et al., 1993). It has also been suggested that vertical migration, tidal and wind-forced currents are a possible mode of recruitment (Rothlisberg et al., 1983; Wenner et al., 1998).

To this day, larval transport and recruitment research has reached considerable progress, for example, on pre-settlement stages as their entrance to inshore habitats is related to biological and oceanographic variables.Despite these advances, knowledge about the larval recruitment of tropical fish species and invertebrates in the Caribbean Sea and Gulf of Mexico is scarce (Criales et al., 2002), due to this in this contribution were analyzed the distribution and abundance of $P$. aztecus mysis stage and the relationships to environmental factors in PNSAV.

\section{MATERIAL AND METHODS}

The PNSAV is located on the continental shelf of the state of Veracruz, off the coast of Boca del Río and Alvarado municipalities, in the southern

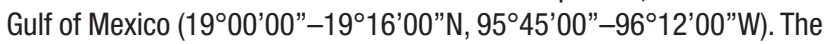
park consists of 23 reef banks divided by the estuarine inlet of the Jamapa River; 12 reefs are in front of the port of Veracruz (northern group) and 11 more are in front of the Municipality of Antón Lizardo (southern group). In total, they occupy an area of 52,283 hectares. The park presents islands and platform reefs (Granados-Barba et al., 2007; Horta-Puga et al., 2007).

The Gulf of Mexico is in a transition area; therefore, seasonal variability is less pronounced in the southern tropical half. For that reason, the climate in the PNSAV cannot be divided seasonally; instead we used dry and rainy seasons and cold fronts (Carrillo et al., 2007). Cold fronts are anticyclonic cold wind currents that enter the Gulf of Mexico from North America, generating strong northern winds, with occasional precipitation and temperature drops (Carrillo et al., 2007; 0jeda et al., 2017), this season occurs from October to March. The 'dry weather conditions' occur from May to June, with scarce rainfall and higher temperatures. The 'rainy weather conditions' occur from July to September, when temperatures and precipitation increase and winds are weaker (Carrillo et al., 2007; Zavala-Hidalgo et al., 2014). The average annual temperature in the reef zone is $26^{\circ} \mathrm{C}$ (Chávez et al., 2007).

Field work. Samples were collected under cold front and rainy weather conditions in the years 2011, 2012, and 2013. P. aztecus larval stages were obtained in 26 sampling stations located in four transects, two transects northward and another two transects southward of the Jamapa river estuarine inlet (Fig. 1). 
Horizontal surface hauls were made on the stations using a 1.5 $\mathrm{m}$-Iong conical net WP2 with a $0.5 \mathrm{~m}$ mouth diameter (surface $=0.196$ $\mathrm{m}^{2}$ ) and $330 \mu \mathrm{m}$ mesh opening with a flowmeter (General Oceanics) to determine the volume of filtered water. The hauls were conducted from a boat with an outboard motor and lasted for $5 \mathrm{~min}$ at an average speed of 3 knots $\left(1.543 \mathrm{~m} \mathrm{~s}^{-1}\right)$, equivalent to an approximate distance of 450 $\mathrm{m}$ and water volume of $350 \mathrm{~m}^{3}$ for each sampling site. Samples were concentrated and fixed in $500 \mathrm{ml}$ flasks with $10 \mathrm{ml}$ of $4 \%$ formaldehyde and neutralized with sodium borate. In situ measurements included salinity, surface temperature of water $\left({ }^{\circ} \mathrm{C}\right)$, and dissolved oxygen $\left(\mathrm{mg} \mathrm{l}^{-1}\right)$ which were measured using a multiparameter water quality portable meter (Hanna HI 9828).

Laboratory work. The biological material was transferred to the Crustacean Laboratory at the Facultad de Estudios Superiores Iztacala of the Universidad Nacional Autónoma de México. Samples were transferred to $70 \%$ alcohol $24 \mathrm{~h}$ after fixation. Larvae and decapodids species sorting was carried employing Calazan (1993) and Dos Santos \& Lindley (2001) identification keys. A Motic SMZ-168 stereoscopic microscope and a Leica DM750 microscope were used. The total number of individuals per species was counted and mysis density was standardized to the number of mysis per $100 \mathrm{~m}^{3}$ (Suárez-Morales \& Gasca, 2000).
Statistical analysis. The generalized least squares (GLS) model was used to compare temperature $\left({ }^{\circ} \mathrm{C}\right)$, salinity, and dissolved oxygen (mgl $\left.{ }^{1}\right)$ under cold front (Cf) and rainy (R) weather conditions (Wc) during three sampling years (2011, 2012, and 2013), transects (Northern, N; North central, Nc; South central, Sc; Southern, S) and shore zones (Fs, Foreshore; Ns, Norshore; Offs, Offshore) (Chowdhury \& Behera, 2019) (Zuur et al., 2007). GLS was performed using SPSS v25.

To test whether the density of the species changed as a function of weather conditions and sampling zones, a two-way factorial design was performed. Zones (three) and weather conditions (two) were considered as fixed orthogonal factors. This design was applied to analyze the density of zoeae using a permutational multivariate analysis of variance (PERMANOVA) test. The values of environmental parameters were arcsine transformed and normalized. The values of the density of the species were transformed into the $\log (n+1)$. The resemblance matrix for the density of the species was achieved using the Bray-Curtis similarity (Clarke \& Gorley, 2016). The analysis was computed with 9999 permutations of residuals in a reduced model. Pairwise tests using a t-statistic were used to identify differences between weather conditions, latitudinal zones and shore zones. PERMANOVA were performed as implemented in the PRIMER V7 and PERMANOVA add-ons (Anderson et al., 2008; Clarke \& Gorley, 2016).

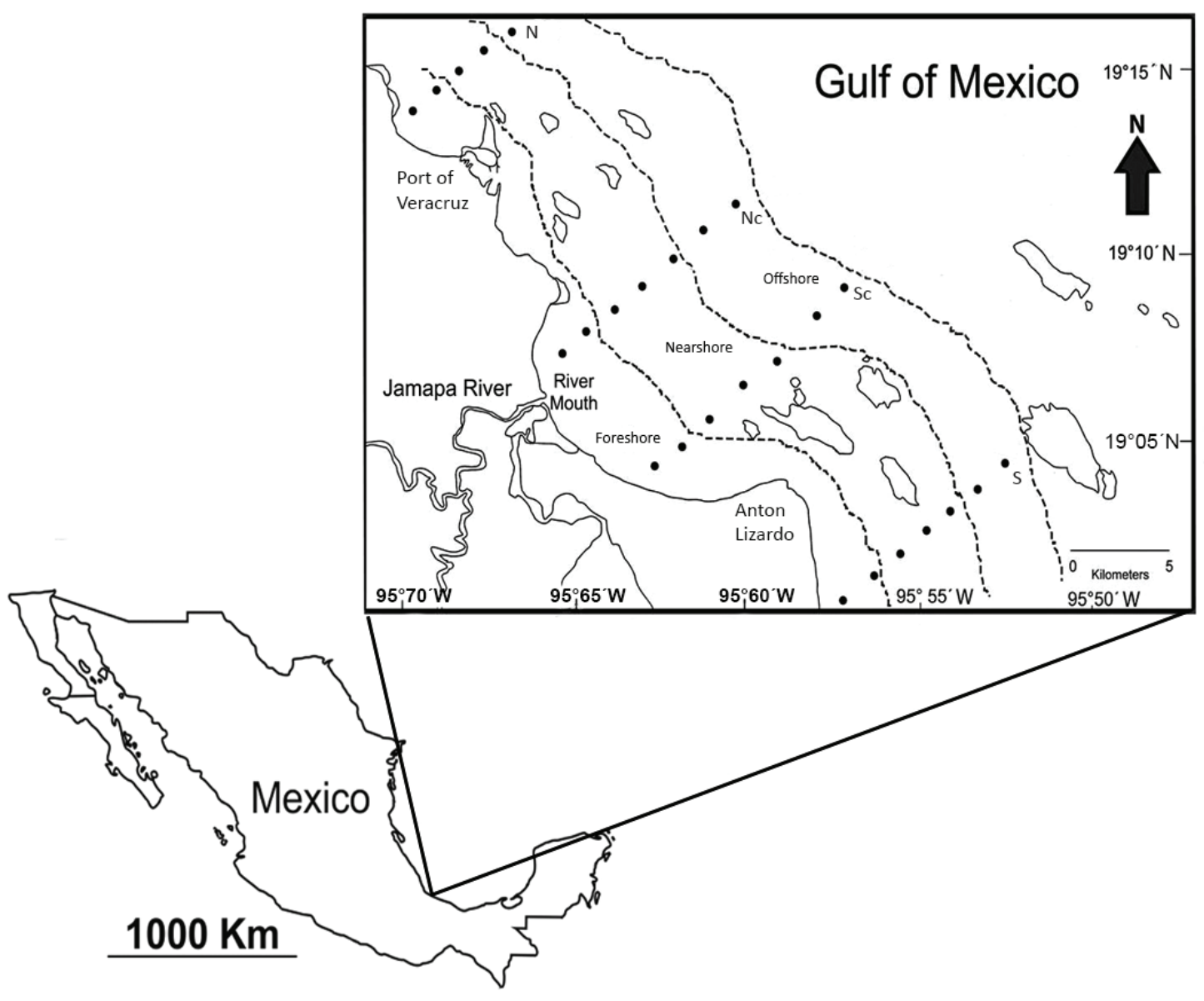

Figure 1. Location of the sampling stations and transects in PNSAV study area. 
The relationships among $P$. aztecus mysis densities and water temperature, salinity and dissolved oxygen mean values were explored with Non-metric multidimensional scaling ordination method (NMDS), using a resemblance matrix constructed with the Bray-Curtis index. NMDS was performed using PAST software (Hammer et al., 2001).

\section{RESULTS}

Environmental factors. In rainy weather conditions, a temperature variation was determined between $27.49 \pm 0.46{ }^{\circ} \mathrm{C}$ in north central-Offs and $29.98 \pm 0.02{ }^{\circ} \mathrm{C}$ in southern-Fs; in weather conditions associated with cold fronts the temperature varied between $23.21 \pm$ $0.05^{\circ} \mathrm{C}$ in north central-Fs and $25.74 \pm 0.37^{\circ} \mathrm{C}$ in southern-Offs (Fig. $2 A)$. The water temperature showed significant differences related to transect location $\left(\mathrm{F}_{(3.61)}=7.310, p<0.001\right)$, shore zone $\left(\mathrm{F}_{(2.61)}=79.757\right.$, $p<0.001)$, and weather condition $\left(\mathrm{F}_{(5,61)}=322.07, p<0.001\right)$. Differences were also found when comparing the northern and north central transects to the southern and south central transects, the three shore zones, and the weather conditions $(p<0.05)$ (Table $1 \mathrm{~A})$.

Salinity in rainy weather conditions was $32.18 \pm 0.06$ in southernFs and $35.40 \pm 0.52$ in the northern-0ffs; in cold front weather conditions, the salinity was $34.59 \pm 0.39$ in the south central-Fs compared to $35.84 \pm 0.17$ in the northern-Offs (Fig. 2b). Salinity Showed significative differences depending on transect $\left(\mathrm{F}_{(3,61)}=9.324, p<0.001\right)$, shore zone $\left(\mathrm{F}_{(2,61)}=30.705, p<0.001\right)$, and weather conditions $\left(\mathrm{F}_{(5,61)}=\right.$ $17.858, p<0.001)$. Northern transect salinity had significant differences with respect to the southern and south central transects (but not with north central transect), and the north central transect salinity showed significant differences with respect to the southern transect only. These salinity differences were found among the three shore zones and the two weather conditions $(p<0.05)$ (Table 1B).

In rainy weather conditions the dissolved oxygen level was $3.64 \pm$ $0.13 \mathrm{mgL}^{-1}$ in the northern-Fs to $6.18 \pm 0.64 \mathrm{mgL}^{-1}$ in the southern-0ffs; in cold front weather conditions dissolved oxygen ranged from $4.04 \pm$ $0.06 \mathrm{mgL}^{-1}$ in the north central-Fs to $6.02 \pm \mathrm{mgL}^{-1}$ in the southern-Offs (Fig. 2c). The dissolved oxygen concentrations showed significant differences depending on transect $\left(\mathrm{F}_{(3,61)}=47.474, p<0.001\right)$, shore zone $\left(\mathrm{F}_{(2,61)}=16.162, p<0.001\right)$, and weather conditions $\left(\mathrm{F}_{(5,61)}=6.588, p\right.$ $<0.001)$. Differences in dissolved oxygen concentrations were found between the northern and the southern and south central transects, the three shore zones, and between cold front conditions in 2011 and 2013 with rainy conditions in 2011, and between cold front weather conditions in 2012 with rainy conditions in 2011 and 2012 (Tukey $p<$ 0.05) (Table 1C).

Mysis density. The highest average density, 6,938 \pm 326 mysis 100 $\mathrm{m}^{-3}$, was found during rainy season in 2011 in the southern transect-Ns, followed by $3,321 \pm 339$ mysis $100 \mathrm{~m}^{-3}$ in the south central-0ffs transect during cold front weather conditions in 2013, and 3,056 \pm 236 mysis $100 \mathrm{~m}^{-3}$ in the south central-Fs transect during cold front weather conditions in 2011 (Table 2). According to the PERMANOVA results, the $P$. aztecus mysis density changed according to weather conditions $\left(\mathrm{F}_{(5,54)}=2.73, p=0.025\right)$ considering the distance off the coastline. The pairwise comparison test revealed that differences in mysis density were apparent among 2013 cold front season and 2012 and 2013 rainy seasons $(p<0.05)$.
Respect to the transects, changes were found among weather conditions $\left(\mathrm{F}_{(3,48)}=5.18, \mathrm{p}=0.004\right)$ and transects too $\left(\mathrm{F}_{(5,48)}=3.38, p=0.009\right)$. The pairwise comparisons revealed that mysis density was different among 2013 cold fronts and 2012 and 2013 rainy season conditions, also among the 2011 cold fronts season conditions and 2012 rainy season conditions $(p<0.05)$. Furthermore, the pairwise comparisons showed differences among northern transect, southern transect and south-central transect; another difference was among north-central transect and the southern transect $(p<0.05)$ (Table 3).
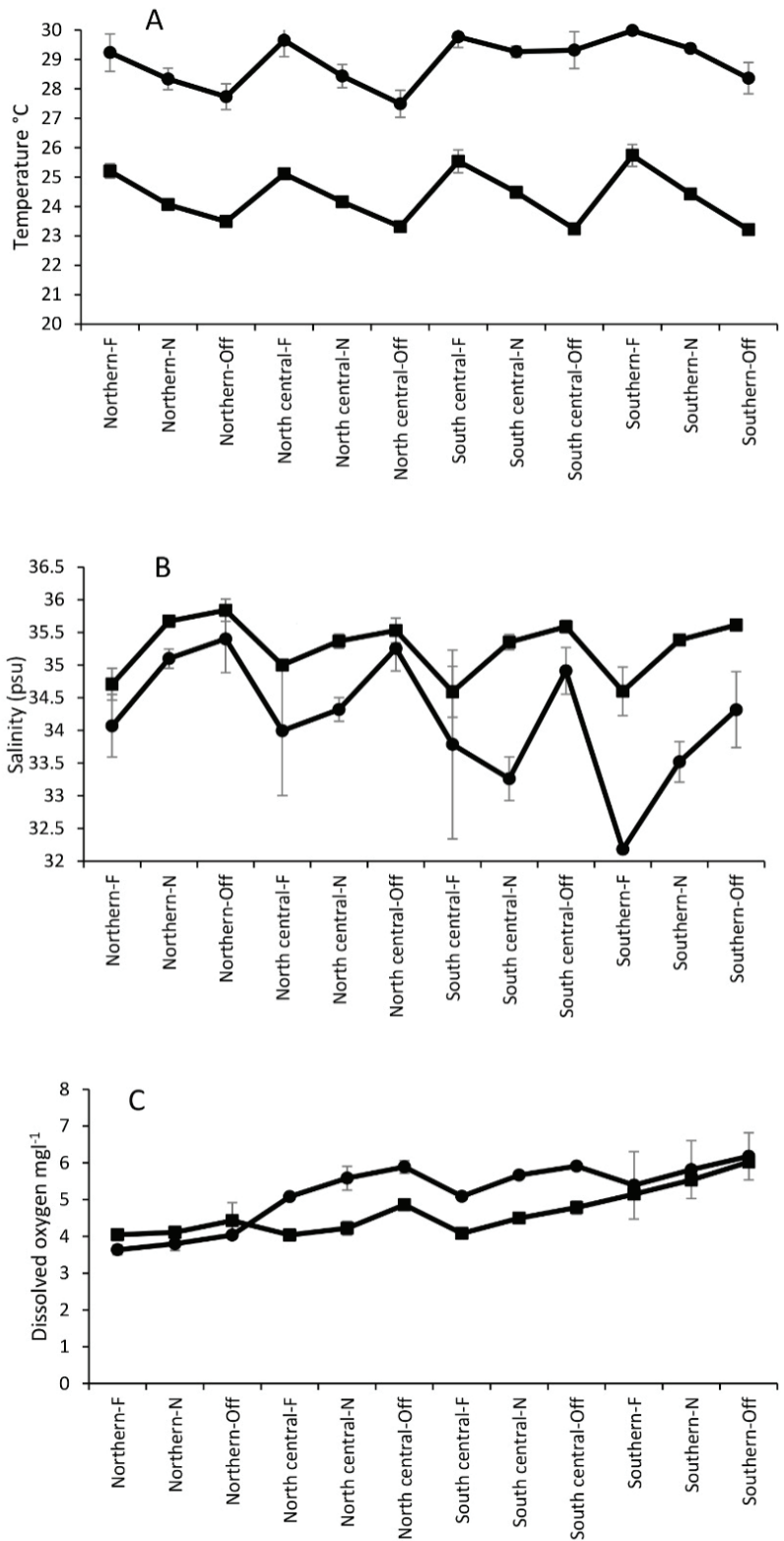

Fig. 2. Relation between the zone of sampling and environmental factors. $A$, temperature ${ }^{\circ} \mathrm{C}$; B salinity (psu); C, dissolved oxygen $\mathrm{mgL}^{-1}$. Black circles, rainy weather conditions; Black squares, cold fronts weather conditions. 
Table 1. Model Generalized Least Squares applied to compare the temperature $\left({ }^{\circ} \mathrm{C}\right)$, salinity (psu) and dissolved oxygen $\left(\mathrm{mgl}^{-1}\right)$ from transects $(\mathrm{Tr})$ and shore zones (Sz) under weather conditions (Wc) for each sampling year. *, significant differences. Cf, cold fronts; Comp, comparison between transects, weather conditions and shore zones; Fs, foreshore; Offs, offshore; N, northern; Nc, north central; Ns, nearshore; R, rainy; S, southern; Sc, south central.

\begin{tabular}{|c|c|c|c|c|c|c|c|}
\hline \multicolumn{8}{|l|}{ Temperature } \\
\hline Corrected model & $178.22^{\mathrm{a}}$ & 10 & 17.82 & 179.15 & $<0.001^{*}$ & $\mathrm{~N}-\mathrm{Nc}$ & 1.000 \\
\hline Intersection & 69363.56 & 1 & 69363.56 & 697255.67 & $<0.001^{*}$ & $\mathrm{~N}-\mathrm{Sc}$ & $0.004^{*}$ \\
\hline $\operatorname{Tr}$ & 2.18 & 3 & 0.73 & 7.31 & $<0.001^{*}$ & $\mathrm{~N}-\mathrm{Sc}$ & $0.016^{*}$ \\
\hline Sz & 15.87 & 2 & 7.93 & 79.76 & $<0.001^{*}$ & Nc-Sc & $0.005^{\star}$ \\
\hline Wc & 160.17 & 5 & 32.03 & 322.02 & $<0.001^{*}$ & Nc-S & $0.021^{*}$ \\
\hline Residual & 6.07 & 61 & 0.09 & & & Sc-S & 0.956 \\
\hline Total & 69547.85 & 72 & & & & Cf-R & $<0.001^{*}$ \\
\hline Corrected total & 184.29 & 71 & & & & Fs-Ns & $<0.001^{*}$ \\
\hline \multirow[t]{2}{*}{$r^{2}=0.97$} & & & & & & Fs-Offs & $<0.001^{*}$ \\
\hline & & & & & & Ns-Offs & $<0.001^{*}$ \\
\hline \multicolumn{8}{|l|}{ Salinity } \\
\hline Source & SC & GI & MC & $\mathbf{F}$ & $\mathbf{p}$ & Comp & p (Tukey) \\
\hline Corrected model & $18.01^{\mathrm{a}}$ & 10 & 1.80 & 17.87 & $<0.001^{*}$ & $\mathrm{~N}-\mathrm{Sc}$ & $0.014^{\star}$ \\
\hline Intersection & 93851.66 & 1 & 93851.66 & 931188.30 & $<0.001^{*}$ & $\mathrm{~N}-\mathrm{S}$ & $<0.001^{*}$ \\
\hline $\operatorname{Tr}$ & 2.82 & 3 & 0.94 & 9.32 & $<0.001^{*}$ & Nc-Sc & 0.246 \\
\hline Sz & 6.19 & 2 & 3.09 & 30.71 & $<0.001^{*}$ & Nc-S & $0.003^{*}$ \\
\hline Wc & 8.99 & 5 & 1.8 & 17.86 & $<0.001^{*}$ & Sc-S & 0.287 \\
\hline Residual & 6.15 & 61 & 0.10 & & & Cf-R & $0.001^{*}$ \\
\hline Total & 93875.82 & 72 & & & & Fs-Ns & $<0.001^{*}$ \\
\hline Corrected total & 24.16 & 71 & & & & Fs-Offs & $<0.001^{*}$ \\
\hline$r^{2}=0.75$ & & & & & & Ns-Offs & $<0.001^{*}$ \\
\hline \multicolumn{8}{|l|}{ Dissolved oxygen } \\
\hline Source & SC & GI & MC & $\mathbf{F}$ & p & Comp & p (Tukey) \\
\hline Corrected model & $66.91^{\mathrm{a}}$ & 10 & 6.69 & 20.77 & $<0.001^{\star}$ & $\mathrm{N}-\mathrm{Nc}$ & $<0.001^{*}$ \\
\hline Intersection & 11720.09 & 1 & 11720.09 & 36378.88 & $<0.001^{*}$ & $\mathrm{~N}-\mathrm{Sc}$ & $<0.001^{*}$ \\
\hline $\operatorname{Tr}$ & 45.88 & 3 & 15.29 & 47.47 & $<0.001^{*}$ & $\mathrm{~N}-\mathrm{S}$ & $<0.001^{*}$ \\
\hline Sz & 10.42 & 2 & 5.21 & 16.16 & $<0.001^{*}$ & Nc-S & $<0.001^{*}$ \\
\hline Wc & 10.61 & 5 & 2.12 & 6.59 & $<0.001^{*}$ & Sc-S & $<0.001^{*}$ \\
\hline Residual & 19.652 & 61 & 0.32 & & & Cf-R & $<0.001^{*}$ \\
\hline Total & 11806.65 & 72 & & & & Fs-Ns & $0.019^{\star}$ \\
\hline Corrected total & 86.56 & 71 & & & & Fs-Offs & $<0.001^{*}$ \\
\hline$r^{2}=0.773$ & & & & & & Ns-Offs & $0.014^{\star}$ \\
\hline
\end{tabular}

The NMDS results identified two groups in rainy seasons, separated by transects (stress $=0.117$ ); one group comprising the northern and north central zones, with low densities and average temperature of $28.68 \pm 0.76{ }^{\circ} \mathrm{C}$, salinity of $34.58 \pm 0.64$ and dissolved oxygen concentration of $4.43 \pm 0.86 \mathrm{mgL}^{-1}$; the second group, with higher densities, was comprised by the southern and south central transects, with average temperature $29.35 \pm 0.56{ }^{\circ} \mathrm{C}$, salinity of $33.66 \pm 0.94$ and dissolved oxygen levels of $5.68 \pm 0.39 \mathrm{mgL}^{-1}$ (Fig. 3a). The NMDS anal- ysis also separated two groups (stress $=0.043$ ) in cold front weather conditions: a group in the northern and north central zones, with low densities and average temperature of $24.41 \pm 0.73^{\circ} \mathrm{C}$, salinity 35.32 \pm 0.47 , and dissolved oxygen levels of $4.16 \pm 0.17 \mathrm{mgL}^{-1}$; the second group, with higher densities, was formed by the southern and south central transects, with average temperature of $24.44 \pm 1.08^{\circ} \mathrm{C}$, salinity of $35.19 \pm 0.47$, and dissolved oxygen concentration of $5.01 \pm 0.71$ $\mathrm{mgL}^{-1}$ (Fig. 3b). 
Table 2. Penaeus aztecus. Density of mysis $100 \mathrm{~m}^{-3}$ (士 SD) in the PNSAV during rainy and cold fronts of 2011, 2012 and 2013. Cold fronts, Cf; Shore zone, Sz; Rainy, R. Bold highest density.

\begin{tabular}{|c|c|c|c|c|c|c|c|}
\hline Transect & $\mathrm{Sz}$ & R-2011 & Cf-2011 & R-2012 & Cf-2012 & R-2013 & Cf- 2013 \\
\hline Northern & Foreshore & & $208 \pm 36$ & & & & $40 \pm 12$ \\
\hline Northern & Noreshore & & $72 \pm 15$ & & $28 \pm 8$ & $184 \pm 22$ & $660 \pm 113$ \\
\hline North central & Foreshore & & & & & $35 \pm 7$ & $80 \pm 25$ \\
\hline North central & Noreshore & $8 \pm 2$ & 9 & $43 \pm 18$ & & & $72 \pm 21$ \\
\hline North central & Offshore & & $40 \pm 12$ & & $33 \pm 10$ & $225 \pm 25$ & $2704 \pm 356$ \\
\hline South central & Foreshore & $49 \pm 14$ & $3056 \pm 236$ & & $56 \pm 16$ & $56 \pm 14$ & $113 \pm 26$ \\
\hline South central & Noreshore & $256 \pm 36$ & $666 \pm 125$ & & $159 \pm 21$ & & $1439 \pm 189$ \\
\hline South central & Offshore & $139 \pm 17$ & & & $272 \pm 56$ & & $3321 \pm 339$ \\
\hline Southern & Foreshore & $1682 \pm 125$ & $20 \pm 6$ & $26 \pm 6$ & $248 \pm 65$ & $13 \pm 3$ & $464 \pm 89$ \\
\hline Southern & Noreshore & $6938 \pm 326$ & $112 \pm 26$ & $59 \pm 12$ & $728 \pm 112$ & & $555 \pm 145$ \\
\hline Southern & Offshore & $64 \pm 11$ & $59 \pm 16$ & & $55 \pm 18$ & $88 \pm 12$ & $872 \pm 258$ \\
\hline
\end{tabular}

\section{DISCUSSION}

Changes in environmental conditions in the PNSAV region during periods of weather associated with a cold front, rainy weather, tropical storms, and hurricanes cause a mixed layer in the water column, incorporating nutrients into the photic zone (Zavala-Hidalgo et al., 2006, 2014), which can be used by phytoplankton, zooplankton such as mysis that feed on the algae (Schwamborn et al., 2001). In cold front weather conditions winds along Tamaulipas and Veracruz coasts produce cyclonic currents in a southerly direction, while those in the states of Campeche Bank and Yucatán form anticyclonic currents. These currents converge at the southern end of the Gulf of Mexico, forming flows, perpendicular to the coast, from the neritic-oceanic zone to the oceanic zone (Zavala-Hidalgo et al., 2006). Furthermore, the subtropical water underlying the Campeche Bank enhances the resuspension of nutrient-rich sediments in the southern part of the PNSAV. Rodríguez-Gómez et al. (2015) found that the highest levels of chlorophyll and, consequently, of gross primary productivity in the PNSAV begin to appear in September and at the end of October to April. Thus, the highest mysis density obtained in this study under rainy weather conditions could be associated to the

Table 3. Permutational multivariate analysis of variance (PERMANOVA) on the density of mysis of Penaeus aztecus from PNSAV reef, based on an orthogonal two-factors model. Cf, cold fronts; Comp, comparison between transects, weather conditions and shore zones; N, northern; Nc, north central; S, southern; Sc, south central; Sz, Shore zones; R, Rainy; Tr, Transects, Wc, Weather conditions. * , significant differences $(p<0.05)$.

\begin{tabular}{|c|c|c|c|c|c|c|c|}
\hline \multicolumn{8}{|c|}{ Shore zones } \\
\hline Source & SS & df & MS & $\mathbf{F}$ & $\mathbf{P}$ & Comp & p (Tukey) \\
\hline $\mathrm{Sz}$ & 0.52 & 2 & 0.26 & 1.12 & 0.312 & Cf2013-R2012 & $0.001^{*}$ \\
\hline Wc & 3.14 & 5 & 0.63 & 2.73 & $0.025^{\star}$ & Cf2013-R2013 & $0.031^{*}$ \\
\hline Interaction & 1.54 & 10 & 0.15 & 0.67 & 0.766 & & \\
\hline Residual & 12.43 & 54 & 0.23 & & & & \\
\hline Total & 17.63 & 71 & & & & & \\
\hline \multicolumn{8}{|l|}{ Transects } \\
\hline Source & SS & df & MS & $\mathbf{F}$ & $\mathbf{P}$ & Comp & p (Tukey) \\
\hline $\operatorname{Tr}$ & 2.8918 & 3 & 0.96394 & 5.18 & $0.004^{*}$ & $\mathrm{~N}-\mathrm{S}$ & $<0.001^{*}$ \\
\hline Wc & 3.1443 & 5 & 0.62885 & 3.38 & $0.009^{\star}$ & $\mathrm{N}-\mathrm{Sc}$ & $0.016^{\star}$ \\
\hline Interaction & 2.655 & 15 & 0.177 & 0.95 & 0.513 & Nc-S & $0.011^{*}$ \\
\hline Residual & 8.9383 & 48 & 0.18621 & & & Cf2011-R2012 & $0.039^{\star}$ \\
\hline Total & 17.629 & 71 & & & & & \\
\hline
\end{tabular}


values of dissolved oxygen, due to the increase in chlorophyll (ÁlvarezCadena et al., 2007), and a response to nutrient input by the estuarine plume of the Jamapa River during rainy conditions (Horta-Puga et al., 2016). However, Landeira \& Lozano-Soldevilla (2018), commented that valuable information is obtained from knowing the place and potential spawning season for a species, and the temporal distribution of decapod larvae suggests a larval hatching period for many species with peaks of abundance associated with seasonality. So, peak spawning from December through April (Zimmerman \& Minello, 1984; Rozas \& Reed, 1993; Matthews, 2008) and a second peak that occurs during late summer and early fall (Rogers et al., 1993) is consistent with the peak of abundance obtained in this study in rainy weather and the continuous presence of high mysis abundance in cold front weather conditions.

The GLS and PERMANOVA tests allow the distinction of two zones: northern zone and southern zone, related to the freshwater inflows and sediment loadings from Jamapa river. However, is important to point out than during cold fronts weather conditions, the inshore marine current turns to a southward direction and Jamapa river plume reaches its highest influence over the nearest reefs to Anton Lizardo coast; in contrast, during dry weather conditions the inshore marine currents go northward and the Jamapa river plume change its influence over the reefs ubicated in front of Veracruz Port (Krutak et al., 1980).

The multivariate analysis (NMDS) results also distinguished two zones, based on dissolved oxygen concentration, since the northern zone had low concentrations (up to $4 \mathrm{mgL}^{-1}$ ) while the northern zone had higher values (up to $5 \mathrm{mgL}^{-1}$ ). According to the EPA (1986) and the ecological Criteria of the European Community (1989), the concentration of dissolved oxygen needed for the protection of aquatic life in both fresh water and marine water is $5 \mathrm{mg} \mathrm{L}^{-1}$. Some aquatic animals can tolerate a lower concentration of dissolved oxygen for a period; however, this has negative effects on biodiversity, growth, and reproduction.

Regarding density, Cházaro-Olvera et al. (2009), found values of 146,530 postlarvae $100 \mathrm{~m}^{-3}$ in the tidal flow of an estuarine lagoon inlet; Wenner et al. (2005) found that the density of $L$. setiferus ranged from 1,300 postlarvae $100 \mathrm{~m}^{-3}$ to 29,900 postlarvae $100 \mathrm{~m}^{-3}$ in surface hauls during night-time flow tides. In the present study we obtained approximately 7,000 mysis $100 \mathrm{~m}^{-3}$ in the nearshore zone in daytime surface hauls. Thus, in open coastal systems dispersion of larvae and postlarvae is higher than in channels where larvae enter estuarine systems.

Finally, with respect to $P$. aztecus life history, Darnell et al. (1983) and Neal et al. (1983) mentioned that adults reproduce in marine environmental conditions beyond the $18 \mathrm{~m}$ depth, and the spawning sites are deeper and far away from shore (Williams, 1984). But the larval distribution, nauplii, protozoea, and mysis stages are found nearby the coast (Sick, 1970; Zimmerman \& Minello, 1984), mainly from September to April (Sandifer, 1973; Williams, 1984). The results showed in this study are consistent evidence of previous reports, referred to highest density of $P$. aztecus mysis was found during rains and cold fronts weather conditions and in the foreshore zone, in this case in the south area of the PNSAV.

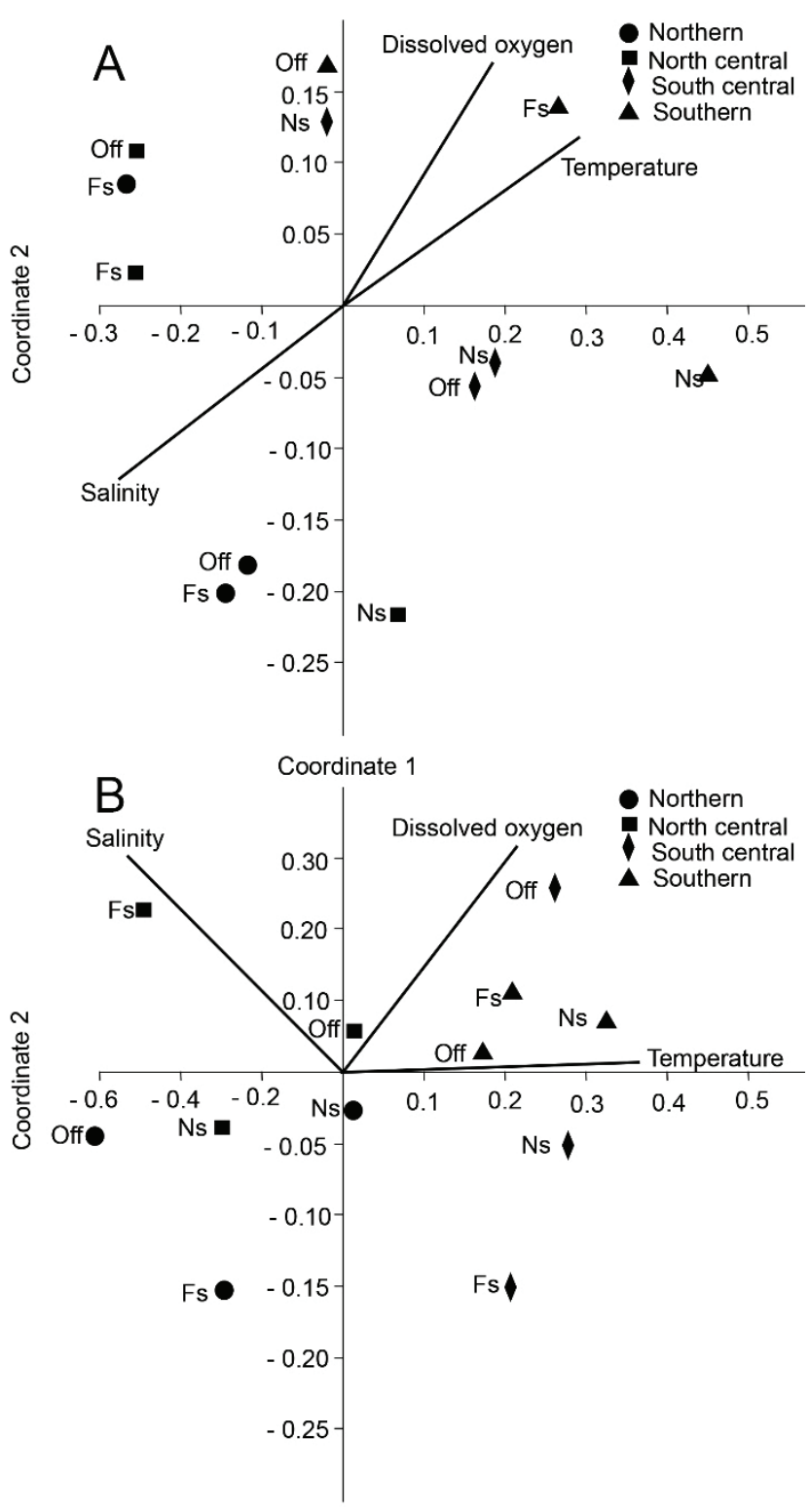

Fig. 3. Penaeus aztecus mysis stage. Non-metric multidimensional scaling (NMDS) for the ordination of density as a function of the weather conditions (A, rainy; B, cold fronts). Fs, foreshore; Ns, nearshore; Offs, offshore).

\section{ACKNOWLEDGEMENTS}

Senior author appreciate the support of CONACYT National Sabbatical Program 2018; the authors express their gratitude towards SEMARNAT, CONANP and CONAPESCA-DGOPA (SAGARPA) authorities for their administrative and permits support for the realization of field work and to the students of the Crustacean Laboratory of FES Iztacala, UNAM, who participated in the processing of samples. 


\section{REFERENCES}

Aguayo-Saviñon, M. A. 1966. Contribución al conocimiento de los Copépodos de la zona arrecifal de Veracruz. Ver. Sistemática y distribución. Tesis de Licenciatura (Biología), Facultad de Ciencias, UNAM. CDMX, México. 74 p.

Álvarez-Cadena, J. N., U. Ordóñez-López, D. Valdés-Lozano, A. R. Almaral \& A. UICAB-SABIDO. 2007. Estudio anual del zooplancton: composición, abundancia, biomasa e hidrología del norte de Quintana Roo, Mar Caribe de México. Revista Mexicana de Biodiversidad 78: 421-430.

Anderson, M. J., R. N. Gorley \& K. R. Clatke. 2008. PeRmanOVA+ for PRIMER: Guide to Software and Statistical Methods. PRIMER-E, Plymouth. Available online at: https://www.primer-e.com/our-software/permanova-add-on/?currency=NZD (downloaded April 20, 2020)

Anger, K. 2001. The biology of decapod crustacean larvae. Crustacean issues. A. A. Bakelma, Lisse, Netherlands. 419 p.

Ayala-Rodríguez, G. A., U. Ordóñez-López, C. Meiners \& M. Marín-Hernández. 2016. Listado taxonómico, aspectos ecológicos y biogeográficos de las larvas de peces del Sistema Arrecifal Veracruzano, Suroeste del Golfo de México (junio 2011-junio 2013). Revista de Biología Marina y Oceanografía 51 (2): 255-264. D0I:10.4067/S071819572016000200004

Calazan, D. 1993. Key to the larvae and decapodids of genera of the Infraorder Penaeidea from the southern Brazilian coast. Nauplius, Rio Grande 1: 45-62.

Campos, A. 1980. Distribución y abundancia relativa de los copépodos planctónicos en el Golfo de México y el Mar Caribe. Ciencias Biológicas (La Habana) 5: 57-74.

Campos-Hernández, A. \& E. Suárez-Morales. 1994. Copépodos pelágicos del Golfo de México y mar Caribe. I. Biología y Sistemática. CIQR0, CONACYT, Regina de los Angeles SA, México. 353 p.

Carrillo, L., G. Horta-Puga \& J. P. Carricart-Ganivet. 2007. Climate and Oceanography. In: Tunnell, J. W. Jr., E. A. Chavez \& K. Withers (eds.). Coral Reefs of the Southern Gulf of Mexico. Texas A \& M University Press, Corpus Christi, Texas, pp. 34-41.

Chávez, E., J. W. Tunnell \& K. Withers. 2007. Reef zonation and ecology. In: Tunnel, J.W., E.A. Chávez \& K. Withers (eds.). Coral reefs of Southern Gulf of Mexico. Texas A \& M University Press, Corpus Christi, Texas, pp. 41-67.

Cházaro-Olvera, S., I. Winfield \& V. Coria-Olvera. 2009. Transport of Farfantepenaeus aztecus postlarvae in three lagoon-system inlets in the southwestern Gulf of Mexico. Crustaceana 82 (4): 425-437. DOl:10.1163/156854008X400612

Cházaro-Olvera, S., J. Montoya-Mendoza, S. Rosales-Saldivar, H. Vázquez-López \& C. Meiners-Mandujano. 2019. Planktonic copepod community of a reef zone in the southern Gulf of Mexico. Journal of Natural History 53 (19-20): 1187-1208. D0I:10.1080/00222933.2 019.1637476

Chowdury, P. \& M. R. BeherA. 2019. Nearshore Sediment Transport in a Changing Climate. In: Venkataraman, C.,T, Mishra, S. Ghosh \& S.
Karmakar (eds.). Climate Change Signals and Response. Springer, Singapore, pp. 48-60.

Clarke, K. R. \& R. N. Gorley. 2016. PRIMER V7: User Manual/Tutorial. PRIMER-e, Plymouth. Available online at: http://updates.primer-e. com/primer7/manuals/User_manual_v7a.pdf (downloaded April 20, 2020)

Criales, M. M., C. Yeung, F. Amaya, A. C. Lopez, D. L. Jones \& W. J. Richards. 2002. Larval supply of fishes, shrimps, and crabs into the nursery ground of the Ciénaga Grande de Santa Marta, Colombian Caribbean. Caribbean Journal of Science 38 (1-2): 52-65.

Darnell, R. M., R. E. Defenbaugh \& D. Moore. 1983. Northwestern Gulf shelf bio-atlas; a study of the distribution of demersal fishes and penaeid shrimp of soft bottoms of the continental shelf from the Rio Grande to the Mississippi River Delta. Open File Report Number 82-04, Minerals Management Service, Gulf of Mexico OCS Regional Office, U.S. Dept. of the Interior. 438 p.

Ditty, J. G., \& J. R. Alvarado-Bremer. 2011. Species discrimination of postlarvae and early juvenile brown shrimp (Farfantepenaeus aztecus) and pink shrimp (F. duorarum) (Decapoda: Penaeidae): Coupling molecular genetics and comparative morphology to identify early life stages. Journal of Crustacean Biology 31 (1): 126-137. DOI:10.1651/10-3304.1

DOF (Diario Oficial de la Federación). 1992. Decreto por el que se declara área natural protegida con el carácter de Parque Marino Nacional, la zona conocida como Sistema Arrecifal Veracruzano, ubicada frente a las Costas de los municipios de Veracruz, Boca del Río y Alvarado del estado de Veracruz Llave, con superficie de 52,238 hectáreas. Comisión Nacional de Áreas Naturales Protegidas (CONANP). Disponible en línea en: http://www.conanp.gob.mx/sig/decretos/parques/sav.pdf (consultado el 15 de marzo 2020).

DOF (Diario Oficial de la Federación). 2012. Diario Oficial de la Federación. Decreto que modifica al diverso por el que se declara Área Natural Protegida, con el carácter de Parque Marino Nacional, la zona conocida como Sistema Arrecifal Veracruzano, ubicada frente a las costas de los municipios de Veracruz, Boca del Río y Alvarado del Estado de Veracruz Llave, con una superficie de 52,238-9150 hectáreas, publicado los días 24 y 25 de agosto de 1992.14 p. Disponible en línea en: https://www.dof.gob.mx/nota_detalle. php?codigo $=5280548 \&$ fecha $=29 / 11 / 2012$ (consultado el 15 de marzo 2020)

Dos Santos, A. \& J. A. Lindley. 2001. Larvae, II. Dendrobranchiata (Aristeidae, Benthesicyemidae, Penaeidae, Solenoceridae, Sicyonidae, Sergestidae, and Luciferidae). ICES Identification Leaflets for Plankton Fiches d'Identification du Plancton, Leaflet No. 186. Copenhagen, Denmark. 9 p. DOl:10.17895/ices.pub.5166

EPA (Environmental Protection Agency, United States). 1986. 'National Recommended Water Quality Criteria. Available online at: https:// www.epa.gov/wqc/national-recommended-water-quality-criteria-tables (downloaded April 12, 2020)

Felder, D. L. \& D. K. Camp. 2009. Gulf of Mexico: Origins, Waters, and Biota. Texas A \& M University Press, Corpus Christi, Texas. 1393 p. 
FIR (Ficha Informativa de los Humedales de Ramsar). 2004. Sitio Ramsar No. 1346 a nivel internacional No. 33 a nivel nacional. $15 \mathrm{p}$.

FLoRes-Coto, C. 1965. Notas preliminares sobre la identificación de las apendicularias de las aguas veracruzanas. Anales del Instituto de Biología, UNAM 36: 293-296.

Flores-Сoto, C. 1974. Contribución al conocimiento de las apendicularias del arrecife "La Blanquilla" Veracruz, México con descripción de una nueva especie. Anales del Centro de Ciencias del Mar Limnología, UNAM 1 (1): 41-60.

Forbes, A. T. \& M. C. Benfield. 1986. Tidal behavior of postlarval penaeid prawns (Crustacea: Decapoda: Penaeidae) in a southeast African estuary. Journal Experimental Marine Biology and Ecology 102 (1): 23-34. DOI:10.1016/0022-0981(86)90123-1

Gómez-Ponce, M. A., C. Flores-Coto, J. López-Martínez, J. L. Cruz-Sánchez \& L. Sanvicente-Añorve. 2018. Evaluation of the entry of white shrimp postlarvae (Decapoda: Penaeidae) to a nursery area in the southern Gulf of Mexico. Latin American Journal of Aquatic Research 46 (1): 166-175. D0I:10.3856/vol46-issue1-fulltext-16

Gracia, A. \& L. Soto. 1990. Population study of the penaeid shrimp of Terminos Lagoon, Campeche, México. Anales del Instituto de Ciencias del Mar Limnología, UNAM 17 (2): 241-255.

Granados-Barba, A., L. G. Abarca-Arenas \& J. M. Vargas-Hernández. 2007. Investigaciones Científicas en el Sistema Arrecifal Veracruzano. Universidad Autónoma de Campeche, Campeche, México. 304 p.

Hammer, Ø., D. A. T. Harper \& P. D. Ryan. 2001. PAST: Paleontological statistics software for education and data analysis. Palaeontologia Electrononica 4(1):9. Disponible en línea en: https://palaeo-electronica.org/2001_1/past/issue1_01.htm (downloaded March 15, 2020).

Hermoso-Salazar, M. \& K. Arvizu-Coyotzl. 2015. Crustáceos del Sistema Arrecifal Veracruzano. In: Granados-Barba, A., L. D. Ortiz-Lozano, D. Salas-Monreal \& C. González-Gándara (eds.). Aportes al conocimiento del Sistema Arrecifal Veracruzano: hacia el corredor arrecifal del soroeste del Golfo de México. Universidad Veracuzana, pp. $1-26$.

Horta-Puga, G., J. M. Vargas-Hernández \& J. P. Caricart-Gavinet. 2007. Reef corals. In: Tunnell, J. W., E. Chávez \& K. Withers (eds.). Coral reefs of the southern Gulf of Mexico. Texas A \& M University Press, Corpus Christi, Texas, pp. 95-101.

Horta-Puga, G., S. Cházaro-Olvera, I. Winfield, M. A. Lozano-Aburto \& V. AreNAS-FuENTES. 2016. Heavy metals in macroalgae from the Veracruz Reef System, Southern Gulf of Mexico. Revista Bio Ciencias 3 (4): 326-339. D0I:10.15741/revbio.03.04.07

HUGHES, D. A. 1969. On the mechanisms underlying tide-associated movements of Penaeus duorarum Burkenroad. In: Mistakidis, M. N. (ed.). Proceedings of the world scientific conference on the biology and culture of shrimps and prawns. Vol. 3. FA0, Roma, pp. 867-874.

Hughes, D. A. 1972. On the endogenous control of tide-associated displacements of pink shrimp, Penaeus duorarum Burkenroad. Biological Bulletin 142: 271-280. D0I:10.2307/1540230
INP (Instituto Nacional de Pesca). 2014. Plan de manejo pesquero del camarón café (Farfantepenaeus aztecus) y camarón blanco (Litopenaeus setiferus) en las costas de Tamaulipas y Veracruz. Diario Oficial de la Federación. México, D.F. Marzo 12: 1-58. También disponible en: https://www.gob.mx/inapesca/documentos/ plan-de-manejo-pesquero-de-camaron-cafe-y-blanco

Jordán-Dahlgren, E. 2004. Los arrecifes coralinos del Golfo de México: Caracterización y diagnóstico. In: Caso, M., I. Pisanty \& E. Ezcurra (eds.). Diagnóstico Ambiental del Golfo de México. INE-SEMARNAT. México, pp. 555-570.

Koettker, A.G. \& A. Freire. 2006. Spatial and temporal distribution of decapod larvae in the subtropical waters of the Arvoredo archipelago, SC, Brazil. Iheringia, Série Zoologia 96 (1):31-39. D0I:10.1590/ S0073-47212006000100005

Krutak, P. R., S. Rickles \& R. Gío-Argáez. 1980. Modern ostracod species diversity, dominance and biofaces patterns Veracruz-Antón Lizardo reefs, México. Anales del Centro de Ciencias del Mar y Limnología, UNAM 7 (2): 181-197.

Landeira, J. M. \& F. Lozano-Soldevilla. 2018. Seasonality of planktonic crustacean decapod larvae in the subtropical waters of Gran Canaria Island, NE Atlantic. Scientia Marina 82 (2): 119-134. DOI:10.3989/scimar.04683.08A

LeaL-Rodríguez, D. 1965. Distribución de pterópodos de Veracruz. Anales del Instituto de Biología, UNAM 36: 249-251.

Martin, J. W., M. M. Criales \& A. Dos Santos. 2014. Dendrobranchiata. In: Martin, J. W., J. Olsen \& J. T. Hoeg (eds.). Atlas of crustacean larvae. John Hopkins Univesity Press, Baltimore, pp. 236-242.

Matthews, G. A. 2008. Variability in estimating abundance of postlarval brown shrimp, Farfantepenaeus aztecus (Ives), migrating into Galveston Bay, Texas. Gulf and Caribbean Research 20 (1): 29-39. DOI:10.18785/gcr.2001.05

Neal, R. A., H. A. Brusher \& L. F. Sullivan. 1983. A survey of brown shrimp resources in the Northwestern Gulf of Mexico 1961-1965. NOAA Technical Memorandum NMFS-SEFC -114, U.S Department of Commerce, National Oceanic and Atmospheric Administration, Washington, D.C., USA. 30 p.

OJedA, E., C.M. Appendini \& E.T. Mendoza. 2017. Storm-wave trends in Mexican waters of the Gulf of Mexico and Caribbean Sea. Natural Hazards and Earth System Sciences 17: 1305-1317. D0I:10.5194/ nhess-17-1305-2017

Okolodkov, Y. B., J. A. Aké-Castillo, M. G. Gutiérrez-Quevedo, H. Pérez-España \& D. Salas-MonReal. 2011. Annual cycle of the plankton biomass in the National Park Sistema Arrecifal Veracruzano, Southwestern Gulf of Mexico. In: Kattel, G. (ed.). Zooplankton and phytoplankton. Nova Science Publishers, Inc, pp. 63-88.

Rodriguez-Gómez, C. F., J. A. Aké-Castilo \& G. Campos-Bautista. 2013. Productividad primaria bruta y respiración planctónica en el Parque Nacional Sistema Arrecifal Veracruzano. Hidrobiológica 23 (2): 143-153.

Rodriguez-Gómez, C. F., J. A. Aké-Castlllo, G. Campos-Bautista \& Y. B. OkoloDKov. 2015. Revisión del estudio del fitoplancton en el Parque Nacional Sistema Arrecifal Veracruzano. E-Bios 2 (8):178-191. 
Rogers, B. D., R. F. Shaw, W. H. Herke \& R. H. Blanchet. 1993. Recruitment of postlarval and juvenile brown shrimp (Penaeus aztecus Ives) from offshore to estuarine waters of the northwestern Gulf of Mexico. Estuarine, Coastal and Shelf Science 36 (4): 377-394. DOl:10.1006/ecss.1993.1023

Rothlisberg, P. C., J. A. Church \& A. M. G. Forbes. 1983. Modeling the advection of vertically migrating shrimp larvae. Journal of Marine Research 41 (3): 511-554. D0I:10.1357/002224083788519759

Rothlisberg, P. C., J. A. Church \& C. B. Fandry. 1995. A mechanism for near-shore concentration and estuarine recruitment of post-larval Penaeus plebejus Hess (Decapoda, Penaeidae). Estuarine, Coastal and Shelf Science 40 (2): 115-138. D0I:10.1016/S02727714(05)80001-0

RozAs, L. P. \& D. J. ReEd. 1993. Nekton use of marsh-surface habitats in Louisiana (U.S.A.) deltaic salt marshes undergoing submergence. Marine Ecology Progress Series 96: 147-157. D0l:10.3354/ meps096147

SANDIFER, P. A. 1973. Distribution and abundance of decapod crustacean larvae in the York River Estuary and adjacent lower Chesapeake Bay, Virginia, 1968-1969. Chesapeake Science 14 (4): 235-257. DOI:10.2307/1350753

Schwamborn, R., S. Neumann-Leitão, T. A. Almeida e Silva, W. E. Pinto-Silva \& U. Saint-PAul. 2001. Distribution and dispersal of decapod crustacean larvae and other zooplankton in the Itamaracá estuarine system, Brazil. Tropical Oceanography, Recife 29 (1): 1-18.

SIck, L. V. 1970. Larval distribution of commercially important Penaeidae in North Carolina. Journal of the Elisha Mitchell Scientific Society 86(3): 118-127.

Sú́rez, M. E. 1992. Composición, distribución, abundancia y zoogeografía de los copépodos pelágicos (Crustacea) del Golfo de México y Mar Caribe mexicanos. Tesis de Doctorado, Facultad de Ciencias, UNAM. CDMX, México. 325 p.

Sú́rez-Morales, E. \& R. Gasca. 2000. The planktonic copepod community at Mahahual reef, Western Caribbean. Biology of Marine Science 66: $255-267$.

UNESCO (Organización de las Naciones Unidas para la Educación, la Ciencia y LA Cultura). 2006. Declaración del Sistema Arrecifal Veracruzano como Reserva de la Biósfera del Programa Hombre y Biósfera de la UNESCO. Disponible en línea en: http://www.unesco.org/new/en/ natural-sciences/environment/ecologicalsciences/biosphere-reserves/latin-america-and-the-caribbean/mexico/sistemaarrecifal-veracruzano (consultado el 11 de marzo 2020)

Vega-Rodriguez, F. 1965. Distribución de Chaetognatha en Veracruz, Ver. Anales del Instituto Biología Serie Zoología, UNAM 36: 229-247.

Wenner, E. L., D. M. Knott, C. A. Barans, S. Wilde, J. 0. Blanton \& J. Amft. 2005. Key factors influencing transport of white shrimp (Litopenaeus setiferus) post-larvae into the Ossabaw Sound system, Georgia, USA. Fisheries Oceanography 14 (3): 175-194. D0l:10.1111/ j.1365-2419.2005.00328.x

Wenner, E. L., D. M. Knott, J. 0. Blanton, C. A. Barans \& J. Amft. 1998. Roles of tidal and wind-generated currents in transporting white shrimp (Penaeus setiferus) post-larvae through a South Carolina (USA) inlet. Journal Plankton Research 20 (12): 2333-2356. DOI:10.1093/plankt/20.12.2333

Wiluams, A. B. 1984. Shrimps, lobsters, and crabs of the Atlantic coast of the Eastern United States, Maine to Florida. Smithsonian Institution Press, Washington, D. C. 550 p.

WoRMS, EditoriAl Board. 2020. World register of marine species. Available online at: (downloaded April 15, 2020)

Zavala-Hidalgo, J., 0. Salmerón, V. Aguilar, S. Cerdeira \& M. Kolb. 2006. Caracterización y regionalización de los procesos oceanográficos de los mares mexicanos. Comisión Nacional para el Conocimiento y Uso de la Biodiversidad (CONABI0). Disponible en línea en: http:// www.conabio.gob.mx/gap/index.php/Procesos_oceanogr\%C3\%A1 ficos(consultado el 02 de mayo 2020)

Zavala-Hidalgo, J., R. Romero-Centeno \& A. Mateos-Jasso. 2014. The response of the Gulf of Mexico to wind and heat flux forcing: what has been learned in recent years. Atmósfera 27 (3): 317-334. DOI:10.1016/S0187-6236(14)71119-1

Zimmerman, R. J. \& T. J. Minello. 1984. Densities of Penaeus aztecus, $P$. setiferus and other natant macrofauna in a Texas salt marsh. Estuaries 7: 421-433. D0l:10.2307/1351623

Zuur, A. F., E. N. Ieno \& G. M. Smith. 2007. Analysing ecological data. Springer, New York, London. 672 p. 